\title{
Regeneration of adsorbents and recovery of heavy metals: a review
}

\author{
S. Lata $\cdot$ P. K. Singh $\cdot$ S. R. Samadder
}

Received: 19 April 2014/Revised: 22 October 2014/ Accepted: 10 November 2014/Published online: 25 November 2014

(C) Islamic Azad University (IAU) 2014

\begin{abstract}
In last a few decades, significant improvements were made in both efficiency and economy for removal of heavy metals and metalloid (arsenic) from water using adsorbents. But less attention was paid to recycling of used adsorbents and recovery of the heavy metals from the desorbing agents. For regeneration and reuse of adsorbents, various possible regenerating agents such as acids, alkalis and chelating agents (such as ethylene diamine tetraacetic acid) were used by many researchers with very limited success in some of the studies only up to a limited number of adsorption-desorption cycles. Only a few of the reported studies were focused on recovery of adsorbed (from saturated adsorbents) and desorbed metals (from regenerating agents). Though the management of the used adsorbent and recovery of heavy metals is one of the most important aspects, but only a limited number of research works considered the fate of spent adsorbents before disposal. This review summarizes the removal efficiency of various adsorbents, desorption efficiency of various regenerating agents and recovery of the heavy metals from both saturated adsorbents and desorbing solvents used for regeneration. The study will help the scientific community working on adsorption studies to take up research initiatives required to address the feasible recovery methods of heavy metals from the used adsorbents, to study the possible reuse of the desorbing agents and to choose a suitable desorbing/regenerating agent for a particular adsorbent.
\end{abstract}

Keywords Adsorbent · Adsorption - Desorption - Heavy metals $\cdot$ Recovery $\cdot$ Regeneration

S. Lata $\cdot$ P. K. Singh $\cdot$ S. R. Samadder $(\bowtie)$

Department of Environmental Science and Engineering, Indian

School of Mines, Dhanbad 826004, India

e-mail: sukh_samadder@yahoo.co.in

\section{Introduction}

Both surface water and groundwater were reported to be contaminated by various contaminants from natural and anthropogenic sources worldwide (Tzou et al. 2007). These contaminants may be organic or inorganic in nature, including heavy metals. Metals such as cadmium (Cd), chromium $(\mathrm{Cr})$, copper $(\mathrm{Cu})$, mercury $(\mathrm{Hg})$, nickel $(\mathrm{Ni})$, lead $(\mathrm{Pb})$ and zinc $(\mathrm{Zn})$ are commonly associated with pollution and toxicity problems (O'Connell et al. 2008). Among metalloids such as boron, silicon, germanium, arsenic, antimony and tellurium, arsenic toxicity is of major concern. In drinking water, arsenic predominantly occurs in inorganic (arsenite, arsenate) and organic forms (methyl and dimethyl arsenic compounds) (Smedley and Kinniburg 2002). It was reported in a study of six administrative blocks of district Murshidabad of West Bengal (India) that about $1,248,580$ people are exposed to arsenic concentrations above $0.05 \mathrm{mg} / \mathrm{L}$ (Samadder 2011). Mercury is another highly toxic heavy metal that should be removed. It is a neurotoxin that can cause damage to the central nervous system. High concentrations of mercury cause impairment of pulmonary and kidney function, chest pain and dyspnoea (Namasivayam and Kadirvelu 1999). Exposure to lead causes anemia, diseases of the liver and kidneys, brain damage and ultimately death (Jain et al. 1989). Though the presence of heavy metals is common in our environment and in the food chain that are necessary for survival of sustainable ecosystem, but excess amount of any of these heavy metals in the food chain may lead to acute or chronic poisoning. Heavy metal toxicity affects the nervous system, reduces energy level, alters blood composition and subsequently affects lungs, kidney, liver and other vital organs. Long-term exposure may lead to muscular and neurological degenerative disorder, including 
alzheimer's disease, parkinson's disease, muscular dystrophy and multiple sclerosis. Repeated exposure to higher concentration of these heavy metals may even cause cancer (Baldwin and Marshal 1999). Heavy metals are nonbiodegradable, persistent and get accumulated in nature and thus are the sources of environmental pollution. Various anthropogenic sources such as industrial effluents, waste water disposal (Praveena et al. 2008), agricultural return flows (Conceição et al. 2013) and domestic sewage release heavy metals into the aquatic environment (Hejabi et al. 2010). Heavy metal(s) are widespread pollutants and pollute the environment such as air (Chiou et al. 2009), soil (Moaref et al. 2014) and water. The presence of these metals in the environment is now a grave matter of concern. To minimize the health risk and for the management of environmental degradation, strict quality standards were imposed for both drinking water and effluent discharge. Compliance with these strict standards is now a major challenge for the industries, drinking water providers and scientists alike for proper treatment of groundwater, surface water and industrial wastewater containing heavy metals (Tzou et al. 2007). There are several physical, chemical or biological techniques that are used for the treatment of groundwater, surface water and wastewater such as coagulation, filtration, flocculation, adsorption, reverse osmosis, activated sludge process, chemical precipitation, membrane separation process and bioremediation. Conventional methods for treating effluents, such as precipitation, redox, membrane technologies and electrolysis, are costly and have problem of secondary waste generation (sludge) (Crini 2005). The safe disposal of sludge is another issue for the industries (Mamatha et al. 2013). Heavy metal(s) and metalloid (arsenic) removal techniques include coagulation and flocculation, precipitation, adsorption, ion exchange and membrane filtration. Alternative methods such as ozone oxidation, bioremediation and electrochemical treatments are also used in the removal of arsenic (Ahmed 2001, 2005; Mandal and Sujuki 2002; Choong et al. 2007). Among the various available techniques for water and wastewater treatment for heavy metal removal, adsorption is considered as the most attractive technique (Mohan and Pittman 2007). Adsorption technique has several advantages over other techniques, such as it is easy to implement in field condition, it has the potential regeneration capacity and the operation is sludge free, and has a high removal efficiency of metal ions (Ahmaruzzaman and Gupta 2011; Wu et al. 2013; Ranjan et al. 2009). Continuous improvements are being reported for the development of effective and suitable adsorbents for achieving higher removal efficiency (Gupta and Nayak 2012). Fu and Wang (2011) found different types of adsorbents such as (1) activated carbon, (2) carbon nanotubes, (3) low-cost adsorbents and (4) bio-adsorbents that have been used for adsorption studies. They suggested that biosorption of heavy metals from aqueous solutions is relatively a new process that has been confirmed as a promising process in the removal of heavy metals. Davis et al. (2003) removed cadmium [Cd(II)], copper [Cu(II)], zinc $[\mathrm{Zn}(\mathrm{II})]$, lead $[\mathrm{Pb}(\mathrm{II})]$, chromium $[\mathrm{Cr}(\mathrm{III})]$ and mercury $[\mathrm{Hg}(\mathrm{II})]$ using the same adsorbent (brown algae). Similarly, Iqbal et al. (2002) performed both adsorption/ desorption study and removed heavy metals such as nickel [Ni(II)], $\mathrm{Pb}(\mathrm{II}), \mathrm{Cd}(\mathrm{II}), \mathrm{Cu}(\mathrm{II}), \mathrm{Cr}(\mathrm{III})$ and $\mathrm{Zn}(\mathrm{II})$ from contaminated water by using bio-adsorbent (petiolar felt sheath of palm-PFP). But in most of the studies, it was found that a single adsorbent was not effective for different types of water pollutants. Adsorption has other limitations also such as it could not achieve a good status at commercial levels due to lack of suitable adsorbents of high adsorption capacity and availability of commercial scale columns (Grassi et al. 2012). Moreover, less attention has been paid to the disposal or recycling of used adsorbents containing adsorbed heavy metals. Gupta et al. (2000) reviewed the efficiency of bio-adsorbents for removal of heavy metal(s) and suggested that biosorption depends on the efficiency of the regeneration of bio-adsorbents after metal desorption. The disposal of used adsorbents containing heavy metal(s) may be done after recovery of contaminants or directly without heavy metal recovery, but in both the cases there will be secondary pollution from the used adsorbents and the chemicals used to treat the adsorbents for metal recovery (Tzou et al. 2007). However, metal-loaded adsorbents have toxic effects on humans and environment. Therefore, the used adsorbents should be released into the environment only after recovery of the heavy metals completely. Considering the need of metal desorption and recovery, this paper summarizes the efficiency of various regenerating agents used by different authors, efficiency of the adsorbents for removal of heavy metals, and recovery of heavy metals.

\section{Review of literature}

The technologies that are available today for the removal of heavy metal(s) can be evaluated on the basis of three main criteria: (a) performance, (b) cost and (c) appropriateness. The appropriateness refers to the technologies that suits better the condition of the place where it has to be applied or installed (Murcott 1999). Apart from this, the technology should meet other technical criteria such as robustness and should not cause any adverse effect on the environment due to by-products of the technique, and the technique should have the capacity to provide water in adequate quantity in different seasons and in varying climatic conditions (Duarte et al. 2009). Vu et al. (2003) 
studied arsenic removal and mentioned that for the developing countries such as Vietnam and Bangladesh, it is not feasible to install large-scale treatment plant for arsenic removal from drinking water and maintain the acceptable limit of arsenic in drinking water $(10-50 \mu \mathrm{g} / \mathrm{l})$. So a lowcost, effective technology applicable at household or at community level is required. Various studies were reported for removal of heavy metals using various adsorbents to achieve a desirable target of removal efficiency. Adsorption on activated carbon has been found to be superior compared to other chemical and physical methods for both water and wastewater treatment in terms of its capability for efficiently adsorbing a broad range of pollutants, fast adsorption kinetics and its simplicity in design (Tan et al. 2008; Bhatnagar et al. 2010). It has been observed that adsorption using different materials such as activated carbon (Huang and Fu 1984; Chuang et al. 2005), activated alumina (Lin and Wu 2001; Singh and Pant 2004), silica gel, basic yttrium carbonate (Wasay et al. 1996a, b), metalloaded coral limestone (Maeda et al. 1990), hematite (Giménez et al. 2007), feldspar (Singh et al. 2002) and hydrous zirconium oxide (Hang et al. 2012) have been used by several researchers. But most of them are not suitable for developing nations due to their high cost, low removal efficiency (Manju et al. 1998; Ranjan et al. 2009) and loss during regeneration (Sud et al. 2008). For this desorption is found to be better solution as it decreases the process cost and also the dependency of the process on a continuous supply of the biosorbent. A successful desorption process requires the proper selection of elutants, which strongly depends on the type of biosorbent and the mechanism of biosorption. Elutant must not damage the biomass and should be cost effective and eco-friendly (Das 2010).

For removal of arsenic from water, Manju et al. (1998) carried out batch studies using copper-impregnated activated coconut husk carbon. They observed maximum adsorption at $\mathrm{pH}$ 12.0. For regeneration of exhausted copper-impregnated activated coconut husk carbon, they used distilled water and $30 \% \mathrm{H}_{2} \mathrm{O}_{2}$ in $0.5 \mathrm{M} \mathrm{HNO}_{3}$ solution separately. After regeneration, the spent adsorbent was treated with acetone and $0.1 \mathrm{M} \mathrm{CuSO}_{4} \cdot 5 \mathrm{H}_{2} \mathrm{O}$ solution to restore original state and used for subsequent runs. Bajpai and Chaudhari (1999) reported a column study and designed an arsenic removal unit using manganese dioxidecoated sand as adsorbent. They suggested the use of $0.2 \mathrm{~N}$ $\mathrm{NaOH}$ solutions as regenerating solution followed by backwashing with the treated water to regenerate the media. During regeneration, $85 \%$ of the removed arsenic was recovered in the first cycle, and then, 94.6-98.3\% arsenic was recovered in the subsequent cycles in column study, but the recovery of arsenic was reduced to $82.3 \%$ on field condition. The study was of limited scope as it did not address the effect of some important factors, such as water $\mathrm{pH}$, concentration and type of competing anions, and cations that form soluble arsenic complexes. Using the same desorbent $(\mathrm{NaOH})$, Xu et al. (2002) performed both column and batch studies for arsenic removal. They found $\mathrm{NaOH}$ effective to desorb the $\mathrm{As}(\mathrm{V})$ from aluminum-loaded Shirasu-zeolite adsorbent. In an another study for arsenic desorption, Thirunavukkarasu et al. (2003) used 41 of $0.3 \mathrm{M} \mathrm{NaOH}$ solution for regeneration of IOCS-2, followed by backwashing with deionized water. In acid digestion during treatment, regeneration and backwashing operation, $8 \%$ of iron was lost from IOCS-2. This loss of iron might lead to decrease in adsorption efficiency. The recoveries of arsenite and arsenate were found to be 80-83 and $84-87 \%$, respectively, up to four cycles (Table 1). Kamala et al. (2005) also considered $\mathrm{NaOH}$ as desorbing agent and performed column study. They used immobilized biomass (Garcinia cambogia) as adsorbent, and they reused over five cycles of loading and elution, while desorption of arsenic from anion exchanger derived from coconut coir pith was carried out using $0.1 \mathrm{M} \mathrm{HCl}$ and 93-96\% regeneration efficiency was achieved (Anirudhan and Unnithan 2007; Table 1). But a small fraction of the adsorbate could not be recovered by regeneration due to very strong bond; as a result, adsorption capacity of the adsorbent reduced in subsequent cycles. $0.1 \mathrm{M} \mathrm{NaOH}$ was proved as a promising regenerating agent in a study by Zhu et al. (2009) as they found nearly $100 \%$ desorption efficiency for arsenic from nano-zero-valent iron (Table 1). No reduction in adsorption efficiency was observed up to 8 cycles of adsorption-desorption studies. But, the recovery of arsenic from the alkaline solution (desorbing agent) was not addressed. Tian et al. (2011) used magnetic wheat straw with varying iron concentrations of $0.1 \mathrm{~mol} / \mathrm{L}$ (MWS1), $0.2 \mathrm{~mol} / \mathrm{L}$ (MWS2) and $0.5 \mathrm{~mol} / \mathrm{L}$ (MWS5), respectively, for arsenic adsorption. The regeneration study of magnetic wheat straw was done using $0.1 \mathrm{~mol} / \mathrm{L} \mathrm{NaOH}$ aqueous solutions, and more than $80 \%$ recycling efficiency was achieved up to 10 cycles (Table 1). In another study, Zhou and Haynes (2012) used three different desorption agents $\left(\mathrm{NaNO}_{3}, \mathrm{HNO}_{3}\right.$ and $\left.\mathrm{NaOH}\right)$ with different concentrations showed better desorption of arsenate $[\mathrm{As}(\mathrm{V})]$ and selenate $[\mathrm{Se}(\mathrm{VI})]$. For regeneration, the metalloaded red mud (adsorbent) was shaken in $0.5 \mathrm{M} \mathrm{NaOH}$ for $1 \mathrm{~h}$ to remove the adsorbed metal. $\mathrm{NaOH}$ was more effective desorbent than $\mathrm{HNO}_{3}$. In first desorption cycle, use of $0.1 \mathrm{~N}$ and $0.5 \mathrm{~N} \mathrm{NaOH}$ was very effective for removing $\mathrm{As}(\mathrm{V})(78-85 \%)$ but was less effective for As(III) (only 26-49 \%).

Zhang et al. (2009) used $0.1 \mathrm{M} \mathrm{NaOH}$ for desorption of $\mathrm{Se}(\mathrm{IV})$ from titanium dioxide nanoparticles and found more than $95 \%$ desorption efficiency. They found 95-105\% recovery for Se(IV) (Table 1). Using same desorbent with different concentration $(0.5 \mathrm{~N} \mathrm{NaOH})$, Zhou 


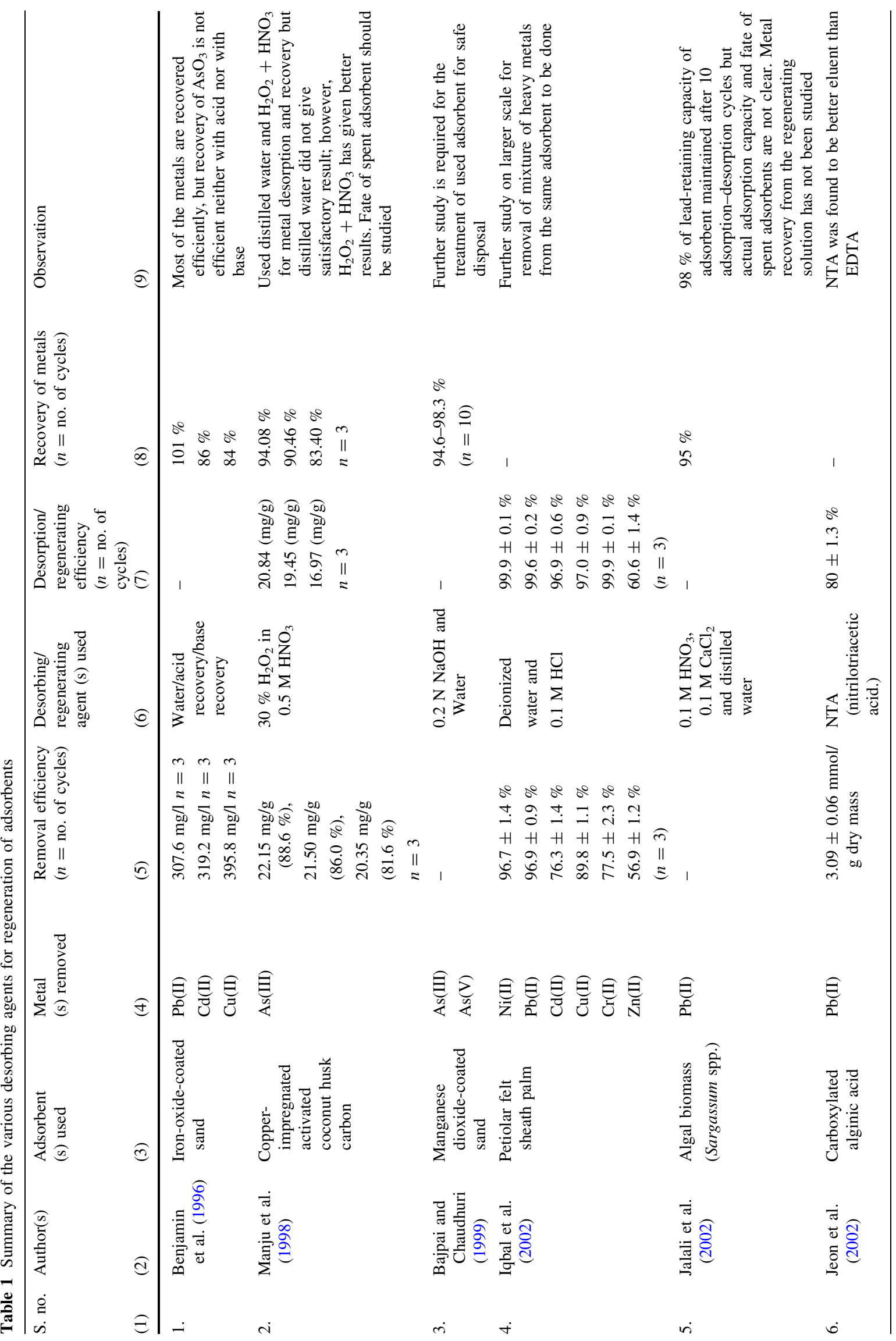




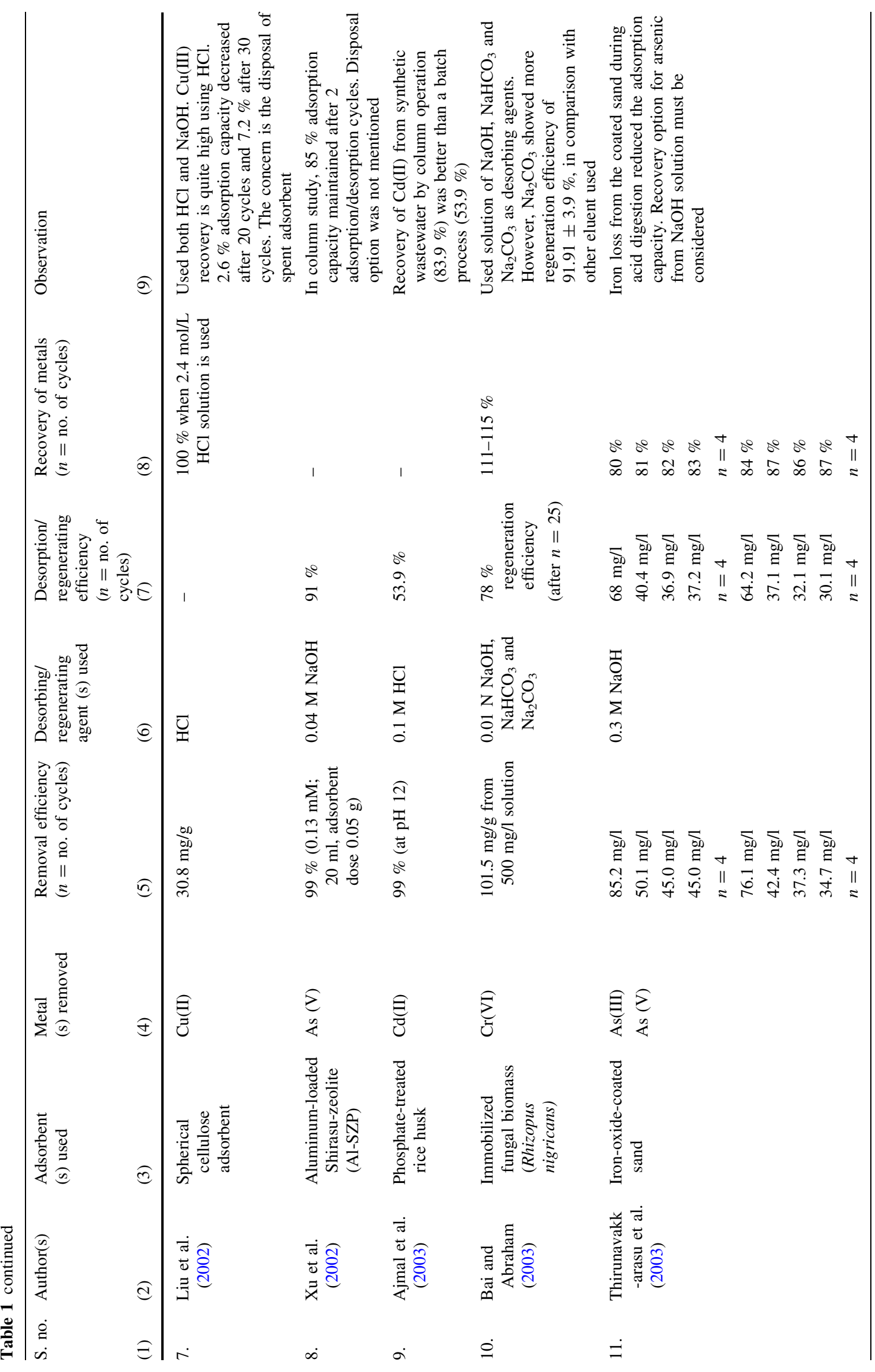




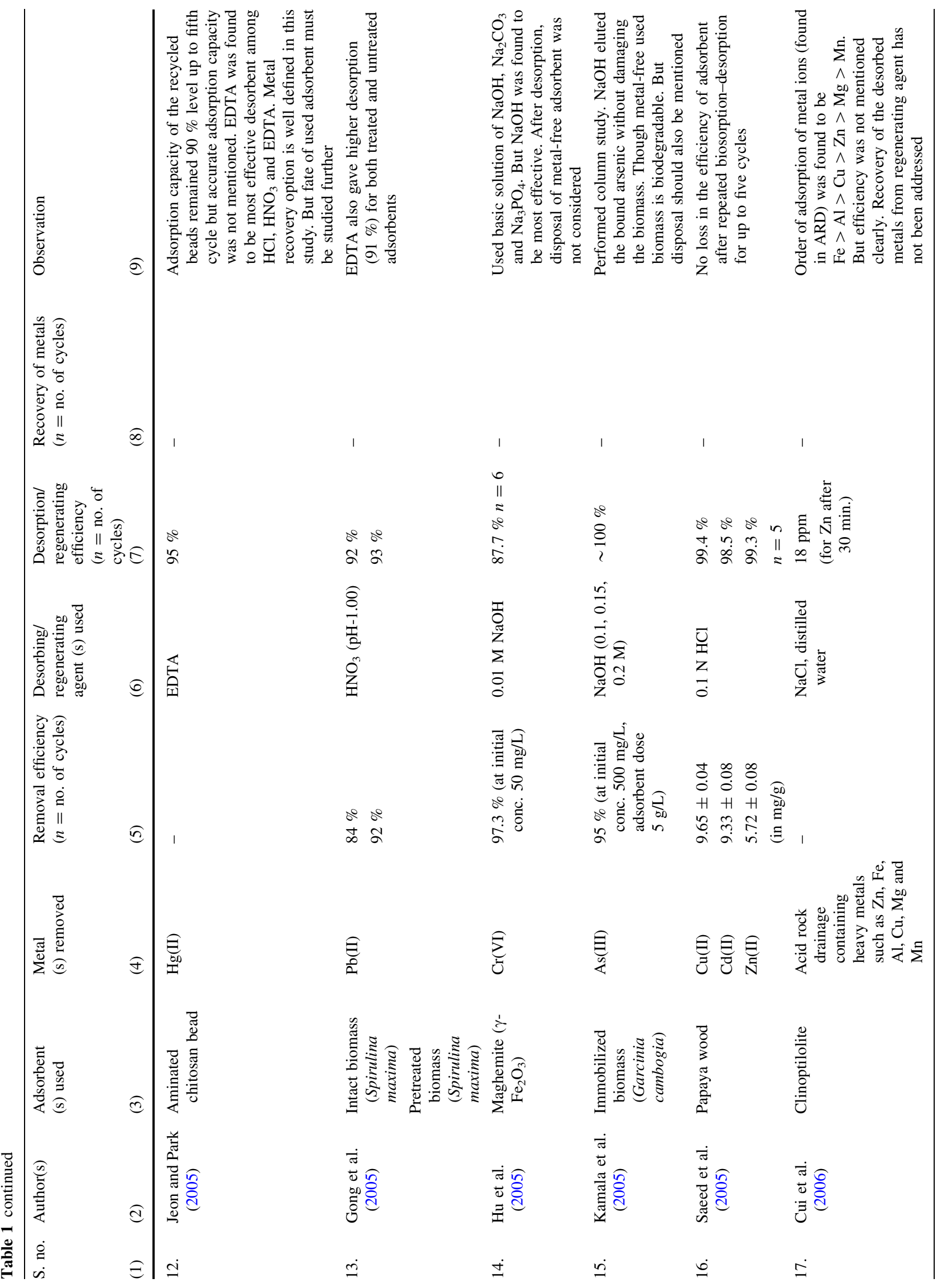




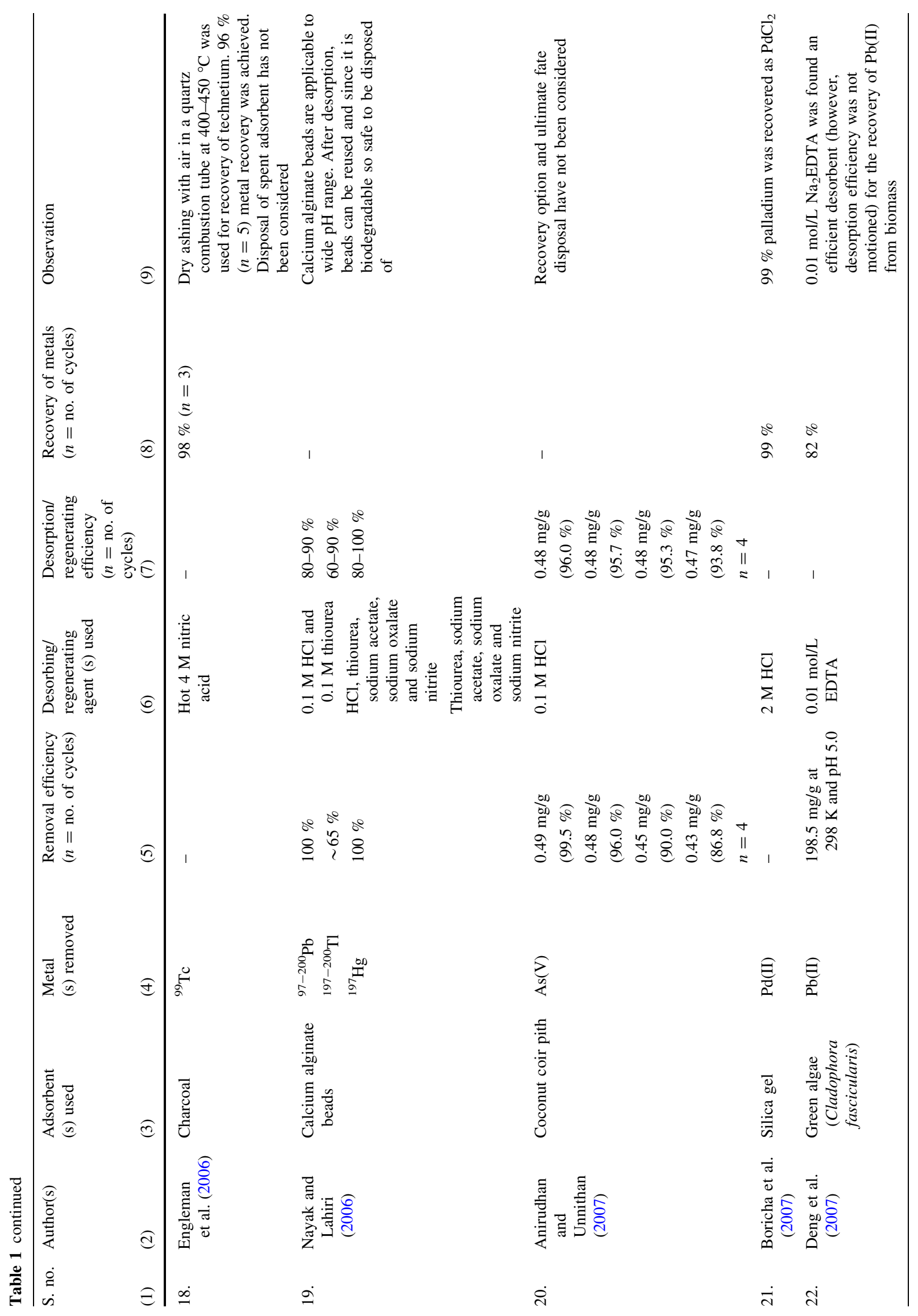




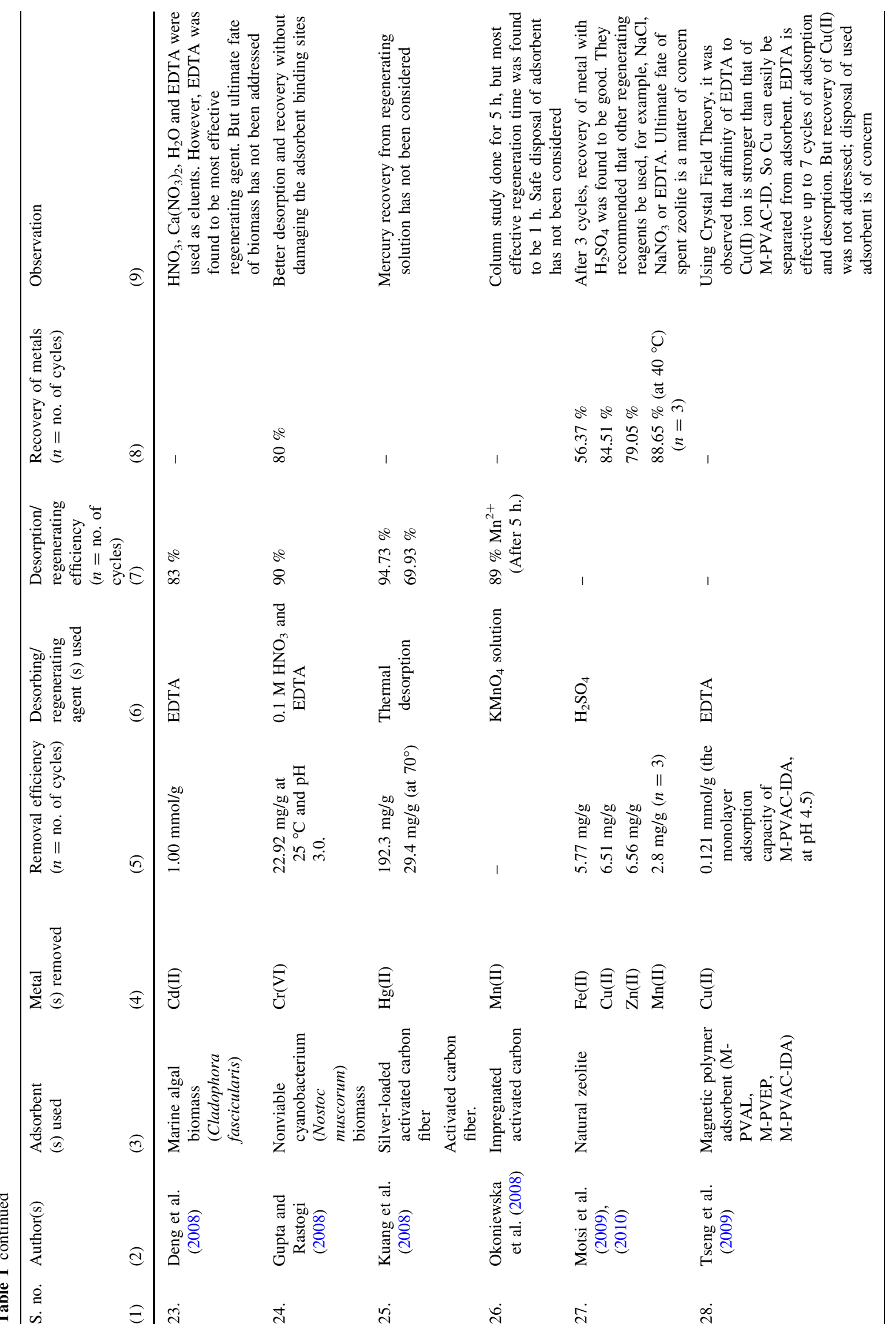




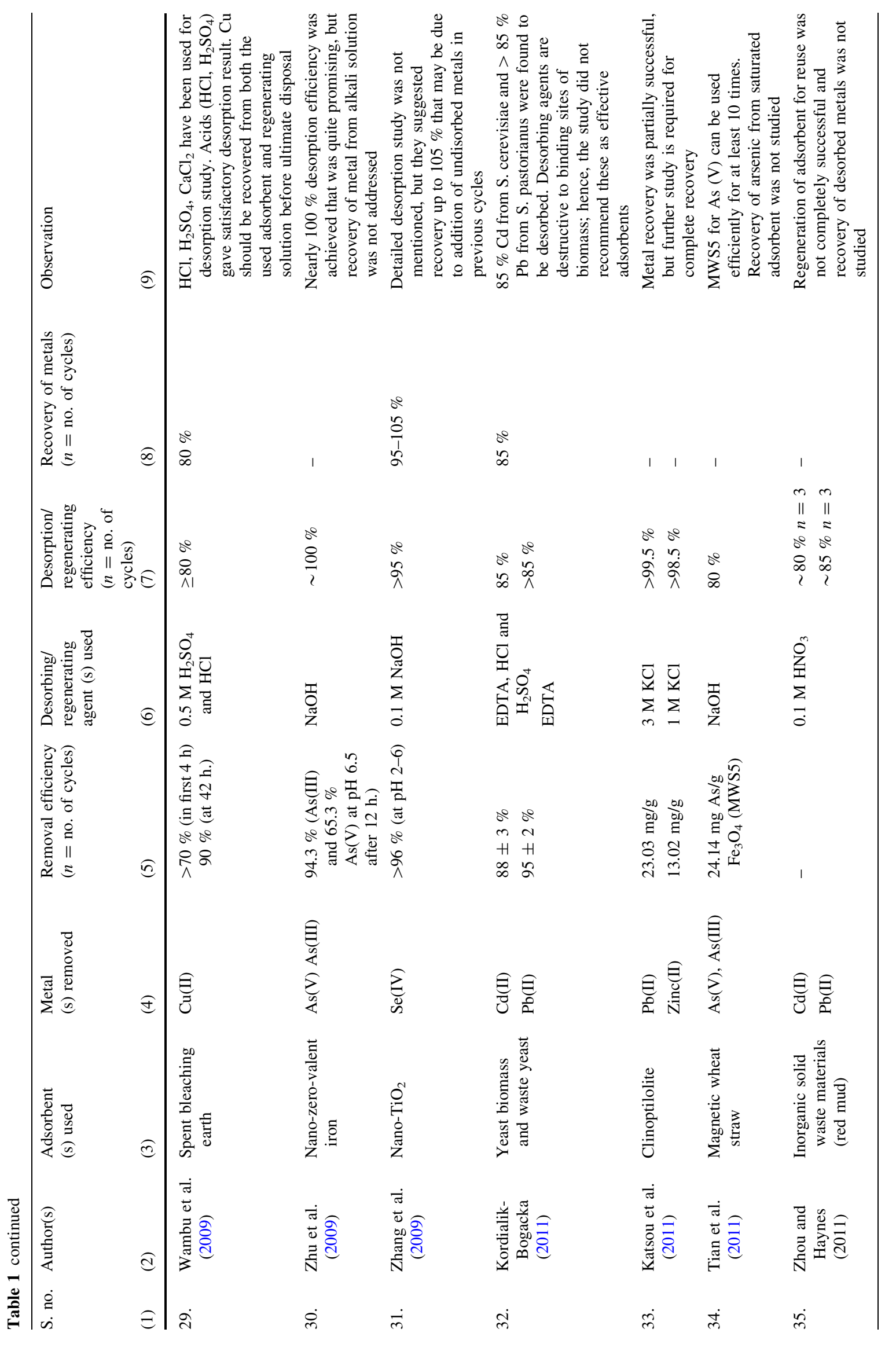




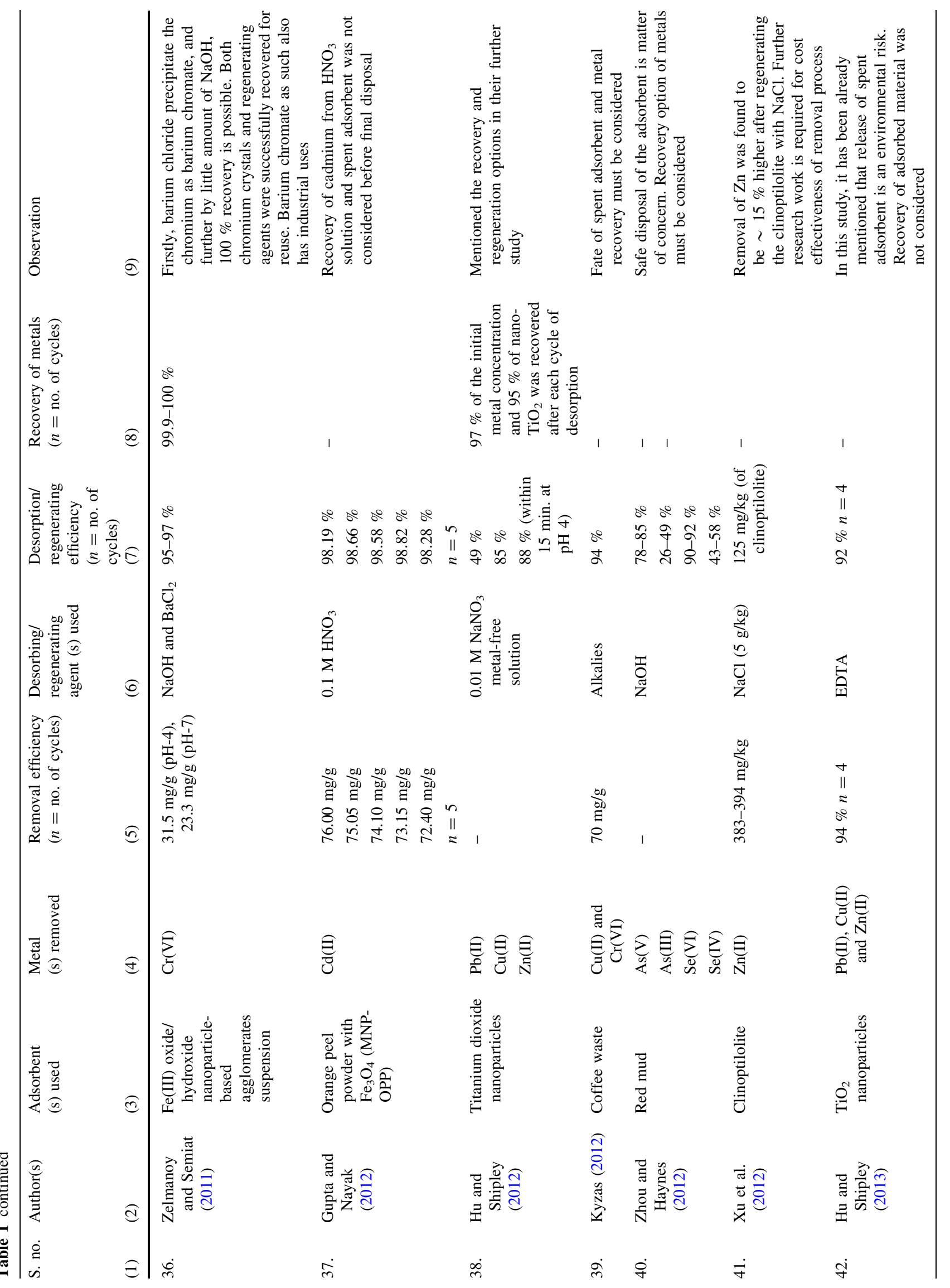


and Haynes (2012) tried to desorb $\mathrm{Se}(\mathrm{VI})$ and $\mathrm{Se}(\mathrm{IV})$ and found desorption efficiency of 90-92 and 43-58\%, respectively.

For the desorption of $\mathrm{Cu}(\mathrm{II})$, Benjamin et al. (1996) used both acid and water for regenerating the adsorbent. The interesting result of their study regarding regeneration was that the regeneration efficiency was $<90 \%$ using water backwashing in first run, but the metal recovery efficiency during the subsequent run was greater than $100 \%$ using backwashing by both water and acid recovery methods. It indicated that metals left on the IOCS during previous regeneration were released in subsequent cycles. Liu et al. (2002) optimized various factors affecting the adsorption and desorption efficiency of $\mathrm{Cu}$ (II). They used a new spherical cellulose adsorbent from aqueous solution and reported that adsorption of $\mathrm{Cu}$ (II) ions was dependent on the initial contact time, $\mathrm{pH}, \mathrm{Cu}(\mathrm{II})$ concentration, and temperature. The $\mathrm{Cu}(\mathrm{II})$ ions adsorbed on the adsorbent were recovered with $\mathrm{NaOH}$ or $\mathrm{HCl}$ aqueous solution. The maximum percentage of recovery was $100 \%$ when $2.4 \mathrm{~mol} / \mathrm{L}$ of $\mathrm{HCl}$ solution was used (Table 1 ). In addition, only $7.2 \%$ of the adsorption capacity was lost after 30 replications of the adsorption-desorption study. Tseng et al. (2009) used ethylene diamine tetraacetic acid (EDTA) to examine the desorption behavior of copper ions adsorbed on the magnetic polymer adsorbent (MPA) of polyvinyl acetate-iminodiacetic acid (M-PVAC-IDA). The $\mathrm{Cu}$ (II) adsorbed on M-PVAC-IDA was recovered by magnetic separation. To recover copper, the EDTA solution of $\mathrm{pH} 5.5$ was used as regenerating solution and mixed with the A-M-PVAC-IDA in the completely stirred tank reactor (CSTR). Each time-saturated EDTA solution was replaced by the fresh EDTA solution, and the process was repeated until no presence of $\mathrm{Cu}$ (II) ion in the desorbing agent (EDTA) solution was detected. In order to continue the adsorption/desorption study, Wambu et al. (2009) conducted a study. For regeneration and possible applicability of spent bleaching earth (SBE), they performed batch study to assess the reversibility of $\mathrm{Cu}$ uptake by spent bleaching earth in $\mathrm{H}_{2} \mathrm{SO}_{4}$ and $\mathrm{CaCl}_{2}$ disclosed that a recovery of $80 \%$ of $\mathrm{Cu}$ was possible using acid. Desorption of $\mathrm{Cu}$ (II) was more effective when $0.25 \mathrm{M} \mathrm{H}_{2} \mathrm{SO}_{4}$ (or $0.5 \mathrm{M} \mathrm{HCl}$ ) was used instead of $0.25 \mathrm{M} \mathrm{CaCl}_{2}$. Recovery of $\mathrm{Cu}$ (II) ions from SBE was successful before the material could be disposed of into the environment. However, when $0.01 \mathrm{M} \mathrm{NaNO}_{3}$ was used as a desorbent, $98 \%$ desorption occurred from nano- $\mathrm{TiO}_{2}$ (anatase) but it was $\mathrm{pH}$ dependent (at pH 2) (Hu and Shipley 2012). In further study, $\mathrm{Hu}$ and Shipley (2013) used EDTA and common ion solutions such as $\mathrm{NaNO}_{3}, \mathrm{CaCl}_{2}, \mathrm{MgSO}_{4}, \mathrm{NaHCO}_{3}, \mathrm{NaCl}$ and $\mathrm{NaHPO}_{4}$ to study the regeneration ability of nano-TiO (anatase) for the recovery of $\mathrm{Pb}(\mathrm{II}), \mathrm{Cu}$ (II) and $\mathrm{Zn}$ (II). The common ions resulted negligible desorption while EDTA gave $92 \%$ desorption (Table 1). Both adsorption and desorption decreased with increased regeneration cycles and the decrease might be due to the stronger chelating property of EDTA that made it difficult to reverse adsorption after continuous cycles (Hu and Shipley 2012). A study was conducted by Kyzas (2012) to understand the applicability of commercial coffee wastes as adsorbent for removal of $\mathrm{Cu}$ (II) from aqueous solutions and the possible reuse of the coffee residuals in sequential adsorptiondesorption cycles. Strong acidic conditions favored desorption of $\mathrm{Cu}$ (II) up to $94 \%$ (Table 1). In contrast, at alkaline condition, the desorption rate was very low. After ten cycles of adsorption-desorption, the reduction in adsorption rate from first to tenth cycle was approximately $7 \%$ for both coffee residues and ions.

Stirk and Staden (2002) found that acids $\left(\mathrm{HCl}, \mathrm{HNO}_{3}\right.$ and $\left.\mathrm{H}_{2} \mathrm{SO}_{4}\right)$ and chloride salts $\left(\mathrm{NaCl}\right.$ and $\left.\mathrm{CaCl}_{2}\right)$ more effective for desorbing cadmium ions than the carbonate salts $\left(\mathrm{NaHCO}_{3}\right.$ and $\left.\mathrm{K}_{2} \mathrm{CO}_{3}\right)$ and chelator $\left(\mathrm{Na}_{2} \mathrm{EDTA}\right)$. Both batch and column studies were performed by Ajmal et al. (2003) who used $\mathrm{HCl}$ for desorption of $\mathrm{Cd}(\mathrm{II})$ from phosphate-treated rice husk. They found less desorption $(53.9 \%)$ during batch study but later it increased $(83.9 \%)$ in column study. In an another adsorption/desorption study of $\mathrm{Cd}(\mathrm{II})$, Deng et al. (2008) used green marine algae biomass (Cladophora fascicularis) as an efficient adsorbent (for wastewater treatment), as it was of low cost and showed maximum adsorption capacity of $1 \mathrm{mmol} / \mathrm{g}$. The effects of anions (chloride, nitrates, sulfate, acetate and EDTA) on the adsorption capacity of Cd(II) were studied and observed that with the change in concentration of EDTA from 1 to $10 \mathrm{mmol} / \mathrm{L}$, the removal efficiency of $\mathrm{Cd}$ (II) reduced from 57 to $20 \%$ and it was concluded that Cd(II) had strong bond with EDTA than the biomass, and, hence it could be used as an effective agent for recovering $\mathrm{Cd}(\mathrm{II})$. Out of the various desorbing agents $\left[\left(\mathrm{H}_{2} \mathrm{O}_{2}, \mathrm{HNO}_{3}\right.\right.$, $\mathrm{Ca}\left(\mathrm{NO}_{3}\right)_{2}$, EDTA)] used for desorption of $\mathrm{Cd}(\mathrm{II})$, Deng et al. (2008) found EDTA as preferable desorbent (83\% desorption) (Table 1). Considering EDTA as an efficient desorbing agent for heavy metal removal from biomass a study of cadmium and lead recovery from yeast biomass (using Saccharomyces pastorianus, Sachharomyces cerevisiae and waste yeast), Kordialik-Bogacka (2011) found that the highest cadmium and lead uptake was obtained with Sachharomyces cerevisiae and all the biomasses had higher lead adsorption capacity than cadmium. They used different desorbing agents such as $\mathrm{HCl}, \mathrm{HNO}_{3}, \mathrm{H}_{2} \mathrm{SO}_{4}$, $\mathrm{Na}_{2} \mathrm{SO}_{4}, \mathrm{Na}_{2} \mathrm{CO}_{3}$, EDTA and $\mathrm{NaOH}$ and found EDTA and mineral acids effective (Table 1). They concluded that even having high desorption capacity these desorbents are inefficient as they damage the binding sites of adsorbent. However, in subsequent adsorption cycle with $S$. pastorianus to remove cadmium, dramatic decrease in adsorption 
capacity was observed. $\mathrm{HNO}_{3}$ was selected as a regenerating agent by Zhou and Hynes (2011). They compared the heavy metal adsorption capacity of some inorganic waste materials such as air-cooled blast furnace (BF) slag, waterquenched BF slag, steel furnace slag, coal fly ash, coal bottom ash, red mud and water treatment sludge. After initial screening, three of the most promising materials (red mud, air-cooled BF slag and water treatment sludge) were chosen for the adsorption/desorption study of $\mathrm{Cd}$ and $\mathrm{Pb}$. After eight adsorption-desorption cycles, it was concluded that acid $\left(\mathrm{HNO}_{3}\right)$ was not a suitable regenerating agent for slags and red mud due to which further research and development with water treatment sludge as a metal adsorbent was warranted. So the recovery of the metals $(\mathrm{Cd}$ and $\mathrm{Pb}$ ) from acid solution was not solved. Further, Gupta and Nayak (2012) used $0.1 \mathrm{M} \mathrm{HNO}_{3}$ and achieved desorption efficiency of about $98 \%$ that was approximately same for all 5 cycles they studied (Table 1). But after five consecutive cycles, adsorption capacity decreased by $4.74 \%$. They developed an advanced class of adsorbent (magnetic nano-adsorbent) by surface modification of $\mathrm{Fe}_{3} \mathrm{O}_{4}$ nanoparticles (MNP) with orange peel powder (OPP) for the removal of cadmium. This modified adsorbent was the combination of nanotechnology and magnetic separation techniques. This is a noble adsorbent as it has a large surface to volume ratio, easy to synthesize, easy to recover, absence of secondary pollutants, cost effective and environment friendly. Desorption study was done using $0.1 \mathrm{M} \mathrm{HNO}_{3}$ at a temperature of $45{ }^{\circ} \mathrm{C}$ using a rotary shaker (200 rpm) for $30 \mathrm{~min}$.

Lead recovery of $101 \%$ was obtained from iron-oxidecoated sand (Benjamin et al. 1996) (Table 1), while Jalali et al. (2002) studied the bio-adsorption of lead using nonliving biomass of eight different types of brown green and red marine algae. Of the eight algal species, three brown algae namely Sargassum hystrix, S. natans and Padina pavonia were found to be the most efficient in lead removal from aqueous solution. For the recovery of lead, metalladen biomass ( $S$. hystrix) was separated by filtration and suspension in $15 \mathrm{ml}$ of desorbing solution $\left(0.1 \mathrm{M} \mathrm{HNO}_{3}\right)$. The recovered biomass was regenerated with $15 \mathrm{ml}$ of $0.1 \mathrm{M} \mathrm{CaCl}_{2}$ for $15 \mathrm{~min}$ and washed twice with distilled water. Ten cycles of adsorption-desorption experiments were performed; the regeneration process did not damage the biomass and achieved $95 \%$ elution efficiency (Table 1). In a study of regeneration of lead $(\mathrm{Pb})$-loaded clinoptilolite, Katsou et al. (2011) used $3 \mathrm{M} \mathrm{KCl}$ as desorbing agent. With increase in regeneration cycle, regeneration efficiency decreased. But zeolite maintained part of the adsorption potential of lead. The desorption efficiency was found to be more than $99.5 \%$ (Table 1). Zhou and Haynes (2011) also performed regeneration studies, but did not mention the recovery of $\mathrm{Pb}$. Kordialik-
Bogacka (2011) used EDTA for desorption and found more than $85 \%$ desorption rate, and recovery was about $85 \%$ that was quite appreciable in comparison to other regenerating agents (Table 1). In their earlier study, $\mathrm{Hu}$ and Shipley (2012) found unsatisfactory desorption results, but in further study using EDTA as desorbent they found desorption efficiency of $92 \%$ for $\mathrm{Pb}$ from $\mathrm{TiO}_{2}(\mathrm{Hu}$ and Shipley 2013) (Table 1).

Zinc desorption was found to be $18 \mathrm{ppm}$ after $30 \mathrm{~min}$ in an adsorption/desorption study of heavy metals (zinc, iron, aluminum, copper) from acid mine drainage. In cyclic adsorption and desorption study, the adsorption by clinoptilolite remained satisfactory up to six cycles with EDTA and up to nine cycles with $\mathrm{NaCl}$ as regenerating chemicals, respectively. The order of adsorption of various metals on the clinoptilolite particles observed was $\mathrm{Fe}>\mathrm{Al}>$ $\mathrm{Cu}>\mathrm{Zn}>\mathrm{Mg}>\mathrm{Mn}$ on the basis of normalized concentrations (Cui et al. 2006). While recovery of $60.11 \%$ with $\mathrm{NaCl}$ and $79.05 \%$ with $\mathrm{H}_{2} \mathrm{SO}_{4}$ was observed that was less than $\mathrm{Mn}\left(88.65 \%\right.$ with $\mathrm{H}_{2} \mathrm{SO}_{4}$ ) (Motsi et al. 2009; Table 1), Katsou et al. (2011) observed more than $98.5 \%$ desorption efficiency for $\mathrm{Zn}$ from clinoptilolite using $1 \mathrm{M}$ $\mathrm{KCl}$ as desorbent (Table 1). Xu et al. (2012) investigated removal of $\mathrm{Zn}$, regeneration and reuse possibility of clinoptilolite (a low-cost and abundant adsorbent) using $\mathrm{NaCl}$ solutions with different concentrations, $\mathrm{pH}$ and with different adsorbent-regenerant ratio. Regeneration was carried out by suspension of $200 \mathrm{~g}$ of previously used clinoptilolite particles in aqueous $\mathrm{NaCl}$ solution in a column by an upward airflow. The effectiveness of regenerated clinoptilolite for $\mathrm{Zn}$ adsorption was tested using batch study with fresh acid rock drainage (ARD) and was observed that regenerated clinoptilolite achieved $440 \mathrm{mg} /$ $\mathrm{kg}$ of zinc uptake capacity. Tap water was used to prepare regeneration solution of $\mathrm{NaCl}$ instead of deionized water to reduce the cost. But further research work is required to explore $\mathrm{Zn}$ removal in repeated clinoptilolite regeneration cycles to ensure reducing zinc concentration in the product stream at a reasonable cost and continuous remediation. However, $88 \%$ desorption was found within $15 \mathrm{~min}$ at $\mathrm{pH}$ 4 using $\mathrm{NaNO}_{3}$ and $92 \%$ with EDTA from $\mathrm{TiO}_{2}$ nanoparticle (Hu Shipley 2012, 2013). The recovery of $97 \%$ of $\mathrm{Zn}$ and $95 \%$ of $\mathrm{TiO}_{2}$ nanoparticle was also mentioned (Table 1).

Okoniewska et al. (2008) studied the regeneration of Mn from used impregnated activated carbons after adsorption. Due to the specificity of activated carbon impregnation, it was possible to use only chemical regeneration and $\mathrm{KMnO}_{4}$ was used as a regeneration agent. Floodingimpregnated activated carbons by $\mathrm{KMnO}_{4}$ solution for $1 \mathrm{~h}$ contact time with regenerating bed resulted in decrease of desorption efficiency (as both decrease and increase in the contact time with $\mathrm{KMnO}_{4}$ solution further decreased 
desorption efficiency). Mn recovery of $88.65 \%$ was obtained with $\mathrm{H}_{2} \mathrm{SO}_{4}$ (Motsi et al. 2009), while $\mathrm{NaCl}$ did not give satisfactory result (Cui et al. 2006). The recovery of $\mathrm{Fe}$ using $\mathrm{H}_{2} \mathrm{SO}_{4}$ and $\mathrm{NaCl}$ as regenerating agent was found to be 56.37 and $12.72 \%$, respectively (Cui et al. 2006 and Motsi et al. 2009; Table 1).

For Chromium removal, immobilized powdered biomass (Rhizopus nigricans) was prepared by entrapping in polymeric matrices-sodium alginate, polyacrylamide, polyvinyl alcohol (PVA), polyisoprene and polysulfone by physical attachment to inert support materials, polyurethane foam cubes and coir fiber. Among these polymeric beads, polyisoprene and polysulfone were identified as the superior matrices for immobilization. The study reported that all the five types of immobilized beads and gels were resistant to acids. The biomass beads were regenerated and reused in multiple cycles that exhibited approximately $78 \%$ regeneration efficiency after 25 cycles of adsorptiondesorption (Bai and Abraham 2003) (Table 1). But the disposal option for the saturated adsorbents and the recovery method of the metal from eluents were not addressed. $\mathrm{Hu}$ et al. (2005) found $\mathrm{NaOH}$ as the most effective desorbent in comparison with other desorbents such as $\mathrm{Na}_{2} \mathrm{CO}_{3}$ and $\mathrm{Na}_{3} \mathrm{PO}_{4}$. After six successive cycles, desorption efficiency was found to be $87.7 \%$. Gupta and Rastogi (2008) used deionized water, $0.1 \mathrm{M} \mathrm{HCl}, \mathrm{HNO}_{3}$ and $\mathrm{H}_{2} \mathrm{SO}_{4}, 0.2 \mathrm{M} \mathrm{CaCl}_{2}$ and $\mathrm{MgCl}_{2}, 0.5 \mathrm{M} \mathrm{KOH}$ and $\mathrm{NaOH}, 5 \% \mathrm{HCHO}$, and $0.1 \mathrm{M}$ EDTA for desorption of $\mathrm{Cr}(\mathrm{VI})$ from cyanobacterium (Nostoc muscorum) biomass (adsorbent). They observed that EDTA and $\mathrm{HNO}_{3}$ were most efficient among all the desorbents studied while desorption with deionized water was almost negligible. Zelmanov and Semiat (2011) also aimed at $\mathrm{Cr}(\mathrm{VI})$ removal using iron $\mathrm{Fe}(\mathrm{III})$ oxide/hydroxide nanoparticle-based agglomerates suspension as adsorbent. To reuse the adsorbent and to separate solid powder containing the chromate, a complete separation technique was used. When purification was complete, the loaded adsorbent was separated by filtration. Then, the filtered cake was treated with $\mathrm{NaOH}$ in the $\mathrm{pH}$ range of 9-10 to regenerate the adsorbent. The concentrated $\mathrm{Cr}(\mathrm{VI})$ solution was treated with $\mathrm{BaCl}_{2}$ in order to remove the chromate ions. This technique allowed the recovery of the adsorbent efficiently and the production of concentrated $\mathrm{Cr}(\mathrm{VI})$ solution that might be treated further to obtain chromium crystals during recovery of the cleaning solution. In another study for desorption of chromium from coffee waste, about $94 \%$ chromium (Table 1) was desorbed using alkalis (Kyzas. 2012).

In a study of mercury adsorption and desorption characteristics using novel aminated chitosan bead, desorption efficiency was found satisfactory (Jeon and Park 2005). The mercury-loaded beads were agitated with $100 \mathrm{ml}$ of various desorbing agents including EDTA, $\mathrm{HCl}$ and $\mathrm{HNO}_{3}$.
About $95 \%$ desorption was achieved using EDTA, while using $\mathrm{HCl}$ and $\mathrm{HNO}_{3}$ only 65 and $61 \%$ desorption was achieved, respectively (Table 1 ). The study recommended EDTA as the best desorbing agent. The reusability of the beads was tested by repeating adsorption-desorption study up to 5 cycles. The adsorption capacity of the recycled beads was reported to be maintained at $90 \%$ level up to fifth cycle. In their study, the EDTA metal complexes were successfully separated as solid EDTA and metal (mercury) chloride/sulfate by using hydrochloric acid or sulfuric acid after the elution. The successful separation of solid EDTA and metal chloride/sulfate can be a permanent solution for the disposal problem as the same can be reused. Nayak and lahiri (2006) used calcium alginate beads to adsorb radionuclide of mercury and thallium, because carboxyl groups in the alginate structure enhances the adsorption of many metal ion and biopolymers in the form of beads have advantages in terms of applicability to a wide variety of process configurations even with polluted streams and reusability for repeated runs following recovery. For desorption of metal radionuclide, they used $0.1 \mathrm{M} \mathrm{HCl}$ and $0.1 \mathrm{M}$ thiourea, sodium acetate, sodium oxalate and sodium nitrite as desorbing agents. Kuang et al. (2008) reported good desorption of mercury from silver-loaded activated carbon fiber and activated carbon fiber. Activated carbon fiber was loaded with silver to improve its characteristic elemental adsorption and desorption properties. Thermal desorption characteristics of elemental mercury from the two adsorbents were investigated using thermogravimetric analysis. The mercury desorption from silverloaded activated carbon fiber was achieved up to $94.73 \%$, whereas the same from activated carbon fiber was only $69.93 \%$ (Table 1).

Engelmann et al. (2006) found appreciable recovery of technetium (Tc) and suggested two methods for recovery of technetium adsorbed on charcoal. The first recovery method employed was liquid extraction method that involved extraction of ${ }^{99} \mathrm{Tc}$ from charcoal with a hot 4-M $\mathrm{HNO}_{3}$ leaching, and the second method involved air ashing at elevated temperature of $400-450{ }^{\circ} \mathrm{C}$ to recover ${ }^{99} \mathrm{Tc}$ from the charcoal. The study found an average recovery of 98 and $96 \%$ for first and second methods, respectively (Table 1). When the hot leaching method was repeated three times, recovery enhanced close to $100 \%$. The first method may be more suitable for air filter sampling operations, whereas the second method (relatively simple method) may be easily adapted to recover ${ }^{99} \mathrm{Tc}$ from vegetation and other types of organic samples.

Palladium (Pd) that was adsorbed on the silica gel as palladium phthalocyanine was first thermally calcined in air to partially burn the organic moiety of the complex. Then, $2 \mathrm{M} \mathrm{HCl}$ was added to calcine silica, so that palladium dissolution takes place as $\mathrm{H}_{2} \mathrm{PdCl}_{4}$. After that, the 
palladium was recovered as $\mathrm{PdCl}_{2}$ from the filtrate by adjusting $\mathrm{pH}$ at 6 by adding $0.1-0.5 \mathrm{M} \mathrm{NaOH}$. A recovery of $99 \%$ pure $\mathrm{PdCl}_{2}$ with $99 \%$ palladium was reported (Boricha et al. 2007; Table 1).

\section{Critical discussion}

In heavy metal removal processes, desorption/regeneration of adsorbents is one of the essential aspects as it controls the economy of water treatment technology (Ali 2012). For effective regeneration of adsorbents and metal recovery, acids (such as $\mathrm{HCl}, \mathrm{H}_{2} \mathrm{SO}_{4}, \mathrm{HNO}_{3}, \mathrm{HCOOH}$ and $\mathrm{CH}_{3} \mathrm{COOH}$ ), alkalis (such as $\mathrm{NaOH}, \mathrm{NaHCO}_{3}, \mathrm{Na}_{2} \mathrm{CO}_{3}$, $\mathrm{KOH}$ and $\mathrm{K}_{2} \mathrm{CO}_{3}$ ), salts (such as $\mathrm{NaCl}, \mathrm{KCl},\left(\mathrm{NH}_{4}\right)_{2} \mathrm{SO}_{4}$, $\mathrm{CaCl}_{2} \cdot 2 \mathrm{H}_{2} \mathrm{O}, \mathrm{NH}_{4} \mathrm{NO}_{3}, \mathrm{KNO}_{3}$ and $\mathrm{C}_{6} \mathrm{H}_{5} \mathrm{Na}_{3} \mathrm{O}_{7} \cdot 2 \mathrm{H}_{2} \mathrm{O}$ ), deionized water, chelating agents and buffer solutions (such as bicarbonate, phosphate and tris) were used in various studies. Table 1 presents the performance of various desorbing agents that have been used for desorption of heavy metals, which will help to understand about the applicability of the desorbents.

Use of acids for regeneration and recovery of heavy metals

Desorption of metal ions in acidic media appeared to be rapid and higher than in basic and neutral media (Srivastava and Goyal 2010). Various acids such as $\mathrm{HCl}, \mathrm{H}_{2} \mathrm{SO}_{4}$, $\mathrm{HNO}_{3}, \mathrm{HCOOH}$ and $\mathrm{CH}_{3} \mathrm{COOH}$ were used for desorption of heavy metals in various studies. Zhou and Haynes (2011) reported the possible mechanisms and conditions of desorption by acids. These are as follows: (1) Low $\mathrm{pH}$ favors desorption and/or dissolution of metal cations, (2) strong competition between $\mathrm{H}^{+}$ions and metal cations for adsorption sites causes displacement of cations into the acid solution, (3) acidic condition favors dissolution of Fe and $\mathrm{Al}$ oxide/silicate adsorption surfaces and thus the release of adsorbed/surface-precipitated metals, and (4) acid reacts with residual alkalinity and lowers adsorption capacity. But they did not give detailed explanation about the desorption mechanism. Benjamin et al. (1996) used iron-oxide-coated sand (IOCS) for the removal of both soluble and insoluble fraction of metals using column packed with iron-oxide-coated sand and successfully recovered $\mathrm{Cu}, \mathrm{Cd}, \mathrm{Pb}, \mathrm{Ni}, \mathrm{Zn}$ and $\mathrm{SeO}_{3}$, but were unable to recover $\mathrm{AsO}_{3}$ using acids (Table 1). The regeneration study using both distilled water and $30 \% \mathrm{H}_{2} \mathrm{O}_{2}$ in $0.5 \mathrm{M}$ $\mathrm{HNO}_{3}$ solution was reported as quite successful for the removal of adsorbed arsenic from coconut husk carbon up to three cycles (Manju et al. 1998). For the recovery of $\mathrm{Cu}$ ions, $\mathrm{HCl}$ and $\mathrm{NaOH}$ were used and found $\mathrm{HCl}$ more effective (Liu et al. 2002). Iqbal et al. (2002) used deionized water and $0.1 \mathrm{M} \mathrm{HCl}$ for desorption of heavy metals from PFP up to three cycles and found desorption efficiency more than $90 \%$ for most of the heavy metals studied. $\mathrm{HNO}_{3}$ was used as an eluent during the recovery of lead from algal biomass (Jalali et al. 2002). Liu et al. (2002) reported $100 \%$ recovery of $\mathrm{Cu}^{2+}$ adsorbed on spherical cellulose using $2.4 \mathrm{~mol} / \mathrm{L}$ of $\mathrm{HCl}$ (Table 1 ). Ajmal et al. (2003) found $53.9 \%$ desorption using $0.1 \mathrm{M} \mathrm{HCl}$ as desorbent for $\mathrm{Cd}(\mathrm{II})$ that was not satisfactory, but further in column study the $83.9 \%$ efficiency was found. Saeed et al. (2005) studied desorption up to five cycles using $0.1 \mathrm{~N} \mathrm{HCl}$ and found 99.4, 98.5 and $99.3 \%$ desorption of $\mathrm{Cu}(\mathrm{II}), \mathrm{Cd}(\mathrm{II})$ and $\mathrm{Zn}(\mathrm{II})$, respectively, from papaya wood. In a study of mercury adsorption using novel aminated chitosan beads and desorption characteristics revealed that the desorption efficiency was only about 65 and $61 \%$ by the use of $\mathrm{HCl}$ and $\mathrm{HNO}_{3}$, respectively, (Jeon and Park 2005). In contrast to this, Gong et al. (2005) used $\mathrm{HNO}_{3}$ as desorbing agent and found desorption efficiency of 92 , $93 \%$ from intact or pretreated biomass of Spirulina maxima. Further using the same desorbent $\left(\mathrm{HNO}_{3}\right)$, Engelmann et al. (2006) carried out a study for the recovery of Tc and $98 \%$ recovery rate was achieved. Nayak and Lahri (2006) found the desorption efficiency of approximately $90 \%$ for $\mathrm{Pb}$ and $\mathrm{Tl}$ and $100 \%$ for $\mathrm{Hg}$, respectively, using various desorbing agents in combination with HCL (as mentioned in Table 1). As an efficient desorbing agent, $\mathrm{HCl}$ was also recommended by Boricha et al. (2007) and Anirudhan and Unnithan (2007). They found 99 and $93.8 \%$ recovery of palladium and desorption of arsenic after four successive cycles, respectively. Deng et al. (2008) studied Cd(II) desorption using $\mathrm{HNO}_{3}$ but desorption efficiency was not satisfactory. Wambu et al. (2009) successfully recovered $80 \% \mathrm{Cu}$ using acids $\left(\mathrm{H}_{2} \mathrm{SO}_{4}\right.$ and $\left.\mathrm{HCl}\right)$. Motsi et al. (2009, 2010) performed desorption study for $\mathrm{Fe}, \mathrm{Cu}, \mathrm{Zn}$ and $\mathrm{Mn}$ using $\mathrm{H}_{2} \mathrm{SO}_{4}$ and found good results for $\mathrm{Cu}$ and $\mathrm{Mn}$. Gupta and Nayak (2012) developed magnetic nano-adsorbent by co-precipitating orange peel powder with $\mathrm{Fe}_{3} \mathrm{O}_{4}$ nanoparticles (MNP-OPP) for removal of Cd. For recovery of $\mathrm{Cd}$ from MNP-OPP, they used $\mathrm{HNO}_{3}$ and successfully achieved $98 \%$ desorption (up to five cycles), but Zhou and Haynes (2011) did not recommend acid as a suitable regenerating agent for slags and red mud.

Use of alkalis for regeneration and recovery of heavy metals

Like acids, various alkalis were also used for the desorption studies of adsorbed heavy metals. $\mathrm{NaOH}, \mathrm{NaHCO}_{3}$, $\mathrm{Na}_{2} \mathrm{CO}_{3}, \mathrm{KOH}$ and $\mathrm{K}_{2} \mathrm{CO}_{3}$ were the most commonly used alkalis for desorption and recovery of heavy metals. A good number of studies recommended alkalis as effective desorbing agents, but a few studies could not get 
satisfactory results using alkalis. Even in the same study, authors were unable to get consistent results for different metals (Benjamin et al. 1996). $\mathrm{NaOH}$ was found to be quite effective for recovery of metal up to $94.6-98.3 \%$ in ten successive cycles (Bajpai and Chaudhari 1999). Bai and Abraham (2003) performed the desorption studies using $0.01 \mathrm{~N}$ solutions of acids $\left(\mathrm{HCl}, \mathrm{H}_{2} \mathrm{SO}_{4}, \mathrm{HNO}_{3}, \mathrm{HCOOH}\right.$ and $\left.\mathrm{CH}_{3} \mathrm{COOH}\right)$, alkalis $\left(\mathrm{NaOH}, \mathrm{NaHCO}_{3}\right.$ and $\left.\mathrm{Na}_{2} \mathrm{CO}_{3}\right)$, buffers and salts, but alkalis were recommended as the best desorbents for $\mathrm{Cr}(\mathrm{VI})$ removal from immobilized Rhizopus nigricans. Recovery of arsenic using $\mathrm{NaOH}$ was found to be effective up to $80-87 \%$ from iron-oxide-coated sand (Thirunavukkarasu et al. 2003) and up to $100 \%$ from biomass (Kamala et al. 2005). Hu et al. (2005) also found $\mathrm{NaOH}$ as the most effective desorbing agent (up to six cycles) as it removed $87.7 \%$ of $\mathrm{Cr}(\mathrm{VI})$ from maghemite nanoparticle. In a further study by Zhang et al. (2009), $\mathrm{NaOH}$ again proved to be better desorbing agent as it helped in achieving desorption of $>95 \%$ and recovery of 95-105\% for Se(IV). Zhu et al. (2009) achieved almost $100 \%$ desorption of adsorbed arsenic using alkaline solution $(\mathrm{NaOH})$ from nano-zero-valent iron and recommended $\mathrm{NaOH}$ as a noble desorbing agent, but on the other hand when it was studied for recovery of $\mathrm{Cd}$ and $\mathrm{Pb}$ from yeast biomass, it was less effective in comparison with that of acids (Kordialik-Bogacka 2011; Table 1). $\mathrm{NaOH}$ was also found to be effective up to $80 \%$ desorption from wheat straw (Tian et al. 2011). Zelmanov and Semiat (2011) recovered $\mathrm{Cr}$ from nanoparticles-based agglomerate suspension successfully using $\mathrm{NaOH}$ and $\mathrm{BaCl}_{2}$, but $\mathrm{Hu}$ and Shipley (2013) reported insignificant regeneration ability of common ions $\left(\mathrm{NaNO}_{3}, \mathrm{NaHCO}_{3}, \mathrm{NaCl}\right.$ and $\mathrm{Na}_{2} \mathrm{HPO}_{4}$ ) from nano- $\mathrm{TiO}_{2}$ (anatase). Zhou and Haynes (2012) used $\mathrm{NaOH}$ and $\mathrm{HNO}_{3}$ as desorbents and found $\mathrm{NaOH}$ as an effective desorbent for $\mathrm{As}(\mathrm{V})$ and $\mathrm{Se}(\mathrm{VI})$ up to 85 and $92 \%$, respectively, but $\mathrm{NaOH}$ was less effective for As(III) (only 26-49 \%) and Se(IV) (43-58 \%).

Use of other chemicals for regeneration and recovery of heavy metals

In order to avoid excessive amount of acid-base consumption of chemicals and salt production, Menoud et al. (1995) developed a new recovery method for metallic ions using recyclable chemicals. The idea is to solubilize the heavy metals with soluble strong complexing agents (e.g., EDTA) (Menoud et al. 2000). Jalali et al. (2002) used $0.1 \mathrm{M} \mathrm{CaCl}_{2}$ for regeneration of biomass and found $95 \%$ elution efficiency. Various salts such as $\mathrm{NaCl}, \mathrm{KCl}$, $\left(\mathrm{NH}_{4}\right)_{2} \mathrm{SO}_{4}, \quad \mathrm{CaCl}_{2} \cdot 2 \mathrm{H}_{2} \mathrm{O}, \quad \mathrm{NH}_{4} \mathrm{NO}_{3}, \quad \mathrm{KNO}_{3}$ and $\mathrm{C}_{6} \mathrm{H}_{5} \mathrm{Na}_{3} \mathrm{O}_{7} \cdot 2 \mathrm{H}_{2} \mathrm{O}$ were used for desorption of immobilized biomass of Rhizopus nigricans by Bai and Abraham (2003). EDTA was found to be one of the most effective desorbing agents in many studies. For example, Jeon and Park (2005) reported $95 \%$ desorption capacity of EDTA for mercury loaded on aminated chitosan bead. Tzou et al. (2007) used hot water for the recovery of chromate from Li/Al Layered Double Hydroxides (LDH). Gupta and Rastogi (2008) also supported the EDTA as desorbing agent as it can be reused without losing its adsorption efficiency up to 5 cycles and without damaging the binding sites of adsorbent. Deng et al. $(2007,2008)$ also used EDTA for $\mathrm{Pb}$ (II) and $\mathrm{Cd}(\mathrm{II})$. They recovered $82 \%$ $\mathrm{Pb}$ from green algae (Table 1). For Cd desorption, they studied the effects of five types of anions (chloride, nitrates, sulfate, acetate and EDTA) for removing adsorbed $\mathrm{Cd}(\mathrm{II})$ and reported $83 \%$ desorption. $\mathrm{CaCl}_{2}$ used as desorbent in earlier studies was not effective for recovery of $\mathrm{Cu}$ (II) (Wambu et al. 2009). Tseng et al. (2009) reported EDTA as an effective recovery agent for recovery of $\mathrm{Cu}(\mathrm{II})$ ion. Katsou et al. (2011) investigated the regeneration of clinoptilolite, contaminated with zinc and lead, using $1 \mathrm{M} \mathrm{KCl}$ and $3 \mathrm{M} \mathrm{KCl}$, respectively. Kordialik-Bogacka (2011) tried to recover cadmium and lead from yeast biomass using EDTA, $\mathrm{HCl}$ and $\mathrm{H}_{2} \mathrm{SO}_{4}$ and found $85 \%$ desorption efficiency with EDTA. While studying desorption efficiency using EDTA for $\mathrm{Cu}(\mathrm{II})$, $\mathrm{Zn}$ (II) and $\mathrm{Pb}$ (II) from $\mathrm{TiO}_{2}$ nanoparticles, $\mathrm{Hu}$ and Shipley (2013) achieved $92 \%$ desorption efficiency up to 4 cycles.

Comparing the various studies, it is found that heavy metal(s) from chemical adsorbents such as manganese dioxide-coated sand, iron-oxide-coated sand, nano-zerovalent iron, $\mathrm{Fe}(\mathrm{III})$ oxide/hydroxide nanoparticle-based agglomerate suspension, and magnetic wheat straw were desorbed in most of the cases using alkalis (generally $\mathrm{NaOH}$ ). In case of desorption of heavy metal(s) from bioadsorbents such as copper-impregnated activated coconut husk carbon, spherical cellulose adsorbent, charcoal, coconut coir pith, impregnated activated carbon, inorganic solid waste materials, petiolar felt sheath palm, phosphatetreated rice husk, papaya wood and orange peel powder with $\mathrm{Fe}_{3} \mathrm{O}_{4}$ (MNP-OPP) mostly acids (such as $\mathrm{HCl}, \mathrm{H}_{2} \mathrm{SO}_{4}$ and $\mathrm{HNO}_{3}$ ) were used; while for adsorbents derived from biomass such as green algae (Cladophora fascicularis), Spirulina maxima biomass, nonviable cyanobacterium (Nostoc muscorum) biomass, yeast biomass and waste yeast, and marine algal biomass (Cladophora fascicularis), EDTA was used as desorbing agents successfully in most of the cases.

Instead of chemical adsorbents/chemically modified adsorbents, many researchers opted bio-adsorbents for removal of heavy metals and got promising results with minimum disposal problem as the bio-adsorbents can be degraded easily by microorganisms, but the concern is that is it scientific to directly dispose the spent adsorbent in 
nature? How to recover the adsorbed metals from the adsorbent? What will happen to the recovered material after recovery?

The summary of the various adsorbents used for adsorption of heavy metals, metals removed, metal removal efficiency, desorbing or regenerating agents used for metal recovery, desorption efficiency, metal recovery, and the critical observations of each one of them is presented in Table 1 that will help in further studies on effective regeneration of adsorbents and recovery of heavy metals.

\section{Conclusion}

This paper presents an extensive review of the various desorbing agents used by different authors to regenerate the used adsorbents. An attempt was made to summarize the heavy metal removal efficiency of various adsorbents and performance of various desorbing agents for regeneration of the saturated adsorbents. This study concludes that alkalis are efficient desorbing agents for desorption of heavy metal(s) from chemical adsorbents or chemically modified adsorbents, acids are efficient for desorbing bio-adsorbents, and chelating agent EDTA is the most efficient desorbing agent for biomass desorption. The study found that many of the adsorbents can be reused effectively after regeneration. EDTA was reused in maximum cases without damaging the binding sites and without significant losses in its initial adsorption capacity. Further studies are required on successful separation, recovery of metal/adsorbent and reuse to solve the ultimate disposal problem. The study found that a single regenerating agent that was effective for one adsorbent, but was not necessarily effective for another adsorbent. Further studies are required to develop a noble eluent that can be applicable for many adsorbents, to study the ultimate fate of the metal-loaded spent adsorbents to reduce the secondary pollution, and to recover the metal ions that may be recycled as a raw material for manufacturing industries to reduce the waste to zero. Only a few studies are available on the mechanism of desorption. Therefore, further studies are required to understand the mechanism of desorption such as stripping, thermal desorption, change of chemical conditions, reduction in partial pressure and other forces acting at the time of desorption to help scientific community find the most efficient desorbing agent.

Acknowledgments The authors acknowledge the support provided by the Department of Environmental Science and Engineering, Indian School of Mines, Dhanbad, for carrying out the research work.

\section{References}

Ahmaruzzaman M, Gupta VK (2011) Rice husk and its ash as lowcost adsorbents in water and wastewater treatment. Ind Eng Chem Res 50(24):13589-13613

Ahmed FM (2001) An overview of arsenic removal technologies in Bangladesh and India. Technologies for arsenic removal from drinking water, Bangladesh University of Engineering and Technology (BUET) and United Nations University (UNU), pp 251-269. http://archive.unu.edu/env/Arsenic/Ahmed.pdf (July 27, 2012)

Ahmed MF (2005) Arsenic mitigation technologies in south and east Asia. In: Towards a more effective operational response, vol. 2, Technical Report No. 31303, Water and Sanitation ProgramSouth Asia and the World Bank, pp 166-207

Ajmal M, Rao RAK, Anwar S, Ahmad J, Ahmad R (2003) Adsorption studies on rice husk: removal and recovery of $\mathrm{Cd}(\mathrm{II})$ from wastewater. Bioresour Technol 86:147-149

Ali I (2012) New generation adsorbents for water treatment. Chem Rev 112:5073-5091

Anirudhan TS, Unnithan MR (2007) Arsenic (V) removal from aqueous solutions using an anion exchanger derived from coconut coir pith and its recovery. Chemosphere 66:60-66

Bai RS, Abraham TE (2003) Studies on chromium(VI) adsorptiondesorption using immobilized fungal biomass. Bioresour Technol 87:17-26

Bajpai S, Chaudhari M (1999) Removal of arsenic from ground water by manganese dioxide-coated sand. J Environ Eng 125:782-784

Baldwin DR, Marshal WJ (1999) Heavy metal poisoning and its laboratory investigation. Ann Clin Biochem 36:267-300

Benjamin MM, Sletten RS, Bailey RP, Bennett T (1996) Sorption and filtration of metals using iron oxide coated sand. Water Res 30:2609-2620

Bhatnagar A, Vilar VJP, Botelho CMS, Boaventura RAR (2010) Coconut-based biosorbents for water treatment: a review of the recent literature. Adv Colloid Interface Sci 160:1-15

Boricha AB, Bajaj HC, Ghosh PK, Jasra RV (2007) Recovery of palladium from palladium phthalocyanine complex adsorbed on silica. J Hydrometall 87:140-147

Chiou P, Tang W, Lin CJ, Chu HW, Ho TC (2009) Comparison of atmospheric aerosols between two sites over golden triangle of Texas. Int J Environ Res 3(2):253-270

Choong TSY, Chuaha TG, Robiaha Y, Koaya FLG, Azni I (2007) Arsenic toxicity, health hazards and removal techniques from water: an overview. Desalination 217:139-166

Chuang CL, Fan M, Xu M, Brown RC, Sung S, Saha B, Huang CP (2005) Adsorption of arsenic (V) by activated carbon prepared from oat hulls. Chemosphere 61:478-483

Conceição FT, Navarro GRB, Silva AM (2013) Anthropogenic influences on $\mathrm{Cd}, \mathrm{Cr}, \mathrm{Cu}, \mathrm{Ni}, \mathrm{Pb}$ and $\mathrm{Zn}$ concentrations in soils and sediments in a watershed with sugar cane crops at São Paulo State, Brazil. Int J Environ Res 7(3):551-560

Crini G (2005) Recent developments in polysaccharide-based materials used as adsorbents in wastewater treatment. Prog Polym Sci 30:38-70

Cui H, Li LY, Grace JR (2006) Exploration of remediation of acid rock drainage with clinoptilolite as sorbent in a slurry bubble column for both heavy metal capture and regeneration. Water Res 40:3359-3366

Das N (2010) Recovery of precious metals through biosorption: a review. Hydrometallurgy 103:180-189

Davis TA, Volesky B, Mucci A (2003) A review of the biochemistry of heavy metal biosorption by brown algae. Water Res $37: 4311-4330$ 
Deng L, Su Y, Su H, Wang X, Zhu X (2007) Sorption and desorption of lead(II) from wastewater by green algae Cladophora fascicularis. J Hazard Mater 143:220-225

Deng L, Zhu X, Su Y, Su H, Wang X (2008) Biosorption and desorption of $\mathrm{Cd}^{2+}$ from wastewater by dehydrated shreds of Cladophora fascicularis. Chin J Oceanol Limnol 26:45-49

Duarte AALS, Cardoso SJA, Alcada AJ (2009) Emerging and innovative techniques for arsenic removal applied to a small water supply system. Sustainability 1:1288-1304

Engelmann MD, Metz LA, Ballou NE (2006) Recovery of technetium adsorbed on charcoal. Radioanal Nucl Chem 268:201-204

Fu F, Wang Q (2011) Removal of heavy metal ions from wastewaters: a review. J Environ Manage 92:407-418

Giménez J, Martíneza M, Pabloa JD, Rovirab M, Duroc L (2007) Arsenic sorption onto natural hematite, magnetite, and goethite. J Hazard Mater 141:575-580

Gong R, Ding Y, Liu H, Chen Q, Liu Z (2005) Lead biosorption and desorption by intact and pretreated Spirulina maxima biomass. Chemosphere 58:125-130

Grassi M, Kaykioglu G, Belgiorno V, Lofrano G (2012) Removal of emerging contaminants from water and wastewater by adsorption process. Chapter 2, doi: 10.1007/978-94-007-3916-1_2

Gupta VK, Nayak A (2012) Cadmium removal and recovery from aqueous solutions by novel adsorbents prepared from orange peel and $\mathrm{Fe}_{2} \mathrm{O}_{3}$ nanoparticles. Chem Eng 180:81-90

Gupta VK, Rastogi A (2008) Sorption and desorption studies of chromium(VI) from nonviable cyanobacterium Nostoc muscorum biomass. J Hazard Mater 154:347-354

Gupta R, Khan PAS, Saxena RK, Mohapatra H (2000) Microbial biosorbents: meeting challenges of heavy metal pollution in aqueous solutions. Curr Sci 78(8):25

Hang C, Li Q, Gao S, Shang JK (2012) As(III) and As(V) Adsorption by hydrous zirconium oxide nanoparticles synthesized by a hydrothermal process followed with heat treatment. Ind Eng Chem Res 51:353-361

Hu J, Shipley HJ (2012) Evaluation of desorption of $\mathrm{Pb}(\mathrm{II}), \mathrm{Cu}(\mathrm{II})$ and $\mathrm{Zn}(\mathrm{II})$ from titanium dioxide nanoparticles. Sci Total Environ 431:209-220

$\mathrm{Hu}$ J, Shipley HJ (2013) Regeneration of spent $\mathrm{TiO}_{2}$ nanoparticles for $\mathrm{Pb}(\mathrm{II}), \mathrm{Cu}(\mathrm{II})$, and $\mathrm{Zn}(\mathrm{II})$ removal. Environ Sci Pollut Res 20:5125-5137

Hu J, Chen G, Lo IMC (2005) Removal and recovery of Cr(VI) from wastewater by maghemite nanoparticles. Water Res 39:4528-4536

Huang CP, Fu PLK (1984) Treatment of arsenic (V) containing water by the activated carbon process. J Water Pollut Contl Fed 56(3):233-242

Iqbal M, Saeed A, Akhtar N (2002) Petiolar felt sheath of palm: a new adsorbent for the removal of heavy metals from contaminated water. Bioresour Technol 81:151-153

Jain SK, Vasudevan P, Jha NK (1989) Removal of some heavy metals from polluted water by aquatic plants: studies on duckweed and water velvet. Biol Wastes 28:115-126

Jalali R, Ghafourian H, Asef Y, Davarpanah SJ, Sepeh S (2002) Removal and recovery of lead using nonliving biomass of marine algae. J Hazard Mat B 92:253-262

Jeon C, Park KH (2005) Adsorption and desorption characteristics of mercury(II) ions using aminated chitosan bead. Water Res 393:938-3944

Jeon C, Park JY, Yoo YJ (2002) Characteristics of metal removal using carboxylated alginic acid". Water Res 36:1814-1824

Kamala CT, Chu KH, Char NS et al (2005) Removal of arsenic(III) from aqueous solutions using fresh and immobilized plant biomass. Water Res 39:2815-2826

Katsou E, Malamis S, Tzanoudaki M, Haralambous KJ, Loizidou M (2011) Regeneration of natural zeolite polluted by lead and zinc in wastewater treatment systems. J Hazard Mater 189:773-786
Kordialik-Bogacka E (2011) Cadmium and lead recovery from yeast biomass. Cent Eur J Chem 9:320-325

Kuang M, Yang G, Chen W, Zhang Z (2008) Study on mercury desorption from silver-loaded activated carbon fibre and activated carbon fibre. Fuel Chem Technol 36:468-473

Kyzas GZ (2012) Commercial coffee wastes as materials for adsorption of heavy metals from aqueous solutions. Materials 5(10): $1826-1840$

Lin TF, Wu JK (2001) Adsorption of arsenite and arsenate within activated alumina grains: equilibrium and kinetics. Water Res 35(8):2049-2057

Liu M, Deng Y, Zhan H, Zhang X (2002) Adsorption and desorption of copper(II) from solutions on new spherical cellulose adsorbent. J Appl Poly Sci 84:478-485

Maeda S, Ohki A, Tsurusaki Y, Takeshita T (1990) Selective adsorption of arsenic (V) ion by use of iron(III) hydroxideloaded coral limestone. Sep Sci Technol 25(5):547-555

Mamatha M, Aravinda HB, Puttaiah ET, Manjappa S (2013) Adsorbent from Pongamia Pinnata tree bark for zinc adsorption. Int J Sci Eng Technol 2(1):22-25

Mandal BK, Sujuki KJ (2002) Arsenic round the world: a review. Talanta 58:201-235

Manju GN, Raji C, Anirudhan TS (1998) Evaluation of coconut husk carbon for the removal of arsenic from water. J Water Res 32:3062-3070

Menoud P, Schmidt V, Meyer T, Renken A (1995) Selective separation and recovery of heavy metals from industrial wastewater. Proceedings of the international congress on recovery recycling reintegration (R'95), Geneva, 3, pp. 378-384

Menoud P, Cavin L, Renken A (2000) New regeneration process of heavy-metal-loaded chelating resins. Chem Eng Technol 23:5

Moaref S, Sekhavatjou MS, Hosseini Alhashemi A (2014) Determination of trace elements concentration in wet and dry atmospheric deposition and surface soil in the largest industrial city, southwest of Iran. Int J Environ Res 8(2):335-346

Mohan D, Pittman JCU (2007) Arsenic removal from water/wastewater using adsorbents-A critical review. Int J Miner Process 92:42-48

Motsi T (2010) Remediation of acid mine drainage using natural zeolite. School of Chemical Engineering, the University of Birmingham, United Kingdom

Motsi T, Rowson NA, Simmons MJH (2009) Adsorption of heavy metals from acid mine drainage by natural zeolite. Int $\mathbf{J}$ Miner Process 92:42-48

Murcott S (1999) Appropriate remediation technologies for arseniccontaminated wells in Bangladesh. Presented at arsenic in Bangladesh ground water. Wagner College, Staten Island, New York, pp 27-28

Namasivayam C, Kadirvelu K (1999) Uptake of mercury(II) from wastewater by activated carbon from unwanted agricultural solid by-product: coirpith. Carbon 37:79-84

Nayak D, Lahiri S (2006) Biosorption of toxic, heavy, no-carrieradded radionuclides by calcium alginate beads. J Radioanal Nucl Chem 267(1):59-65

O'Connell DW, Birkinshawb C, O'Dwyer TF (2008) Heavy metal adsorbents prepared from the modification of cellulose: a review. Bioresour Technol 99:6709-6724

Okoniewska E, Lach J, Kacprzak M, Neczaj E (2008) The trial of regeneration of used impregnated activated carbons after manganese sorption. Desalination 223:256-263

Praveena SM, Ahmed A, Radojevic M, Abdullah MH, Aris AZ (2008) Heavy metals in mangrove surface sediment of Mengkabong lagoon, Sabah: multivariate and geo-accumulation index approaches. Int J Environ Res 2(2):139-148

Ranjan D, Talat M, Hasan SH (2009) Biosorption of arsenic from aqueous solution using agricultural residue 'rice polish. J Hazard Mater 166:1050-1059 
Saeed A, Akhterb MW, Iqbal M (2005) Removal and recovery of heavy metals from aqueous solution using papaya wood as a new biosorbent. Sep Purif Technol 45:25-31

Samadder SR (2011) Impact of arsenic pollution on spatial distribution of human development index (HDI). KSCE J Civil Eng 15(6):975-982

Singh TS, Pant KK (2004) Equilibrium, kinetics and thermodynamic studies for adsorption of As(III) on activated alumina. Sep Purif Technol 36:139-147

Singh DB, Tiwary RK, Tewary BK (2002) Feldspar for the treatment of As(III) contaminated water. Water Qual Res J Can 37(4):757-771

Smedley PL, Kinniburg DG (2002) A review of the source, behaviour and distribution of arsenic in natural waters. Appl Geochem 17:517-568

Srivastava S, Goyal P (2010) Reusability of biomaterial: a cost effective approach. Environ Sci Eng 93-96

Stirk WA, Staden JV (2002) Desorption of cadmium and the reuse of brown seaweed derived products as biosorbents. Bot Mar 45:9-16

Sud D, Mahajan G, Kaur MP (2008) Agricultural waste material as potential adsorbent for sequestering heavy metal ions from aqueous solutions: a review. Bioresour Technol 99:6017-6027

Taghinia Hejabi A, Basavarajappa HT, Qaid Saeed AM (2010) Heavy metal pollution in Kabini river sediments. Int $\mathrm{J}$ Environ Res 4(4):629-636

Tan IAW, Ahmad AL, Hameed BH (2008) Preparation of activated carbon from coconut husk: optimization study on removal of 2,4,6- trichlorophenol using response surface methodology. J Hazard Mater 153:709-717

Thirunavukkarasu OS, Viraraghavan T, Subramanian KS (2003) Arsenic removal from drinking water using iron oxide coated sand. Water Air Soil Pollut 142:95-111

Tian Y, Wu M, Lin X, Huang P, Huang Y (2011) Synthesis of magnetic wheat straw for arsenic adsorption. J Hazard Mater 193:10-16

Tseng JY, Chang CY, Chang CF et al (2009) Kinetics and equilibrium of desorption removal of copper from magnetic polymer adsorbent. J Hazard Mater 171:370-377

Tzou Y, Wang S, Hsu L, Chan R, Lin C (2007) Deintercalation of Li/ $\mathrm{Al} \mathrm{LDH}$ and its application to recover adsorbed chromate from used adsorbent. J Appl Clay Sci 37:107-114
Vu KB, Kaminski MD, Nunez L (2003) Review of arsenic removal technologies for contaminated groundwaters. Chemical Engineering Division, ANL-CMT-03/2, Argonne National Laboratory, Argonne, Illinois 60439, The University of Chicago

Wambu EW, Muthakia GK, Shiundu PM, Thiongo KJ (2009) Kinetics of copper desorption from regenerated spent bleaching earth. Am Eurasian J Sci Res 4:317-323

Wasay SA, Haron MJ, Uchiumi A, Tokunaga S (1996a) Removal of arsenite and arsenate ions from aqueous solution by basic yttrium carbonate. Water Res 30(5):1143-1148

Wasay SA, Haron MJ, Tokunaga S (1996b) Adsorption of fluoride, phosphate, and arsenate ions on lanthanum-impregnated silica gel. Water Environ Res 68(3):295-300(6)

Wu Y, Wen Y, Zhou J, Cao J, Jin Y, Wu Y (2013) Comparative and competitive adsorption of $\mathrm{Cr}(\mathrm{VI}), \mathrm{As}(\mathrm{III})$, and $\mathrm{Ni}$ (II) onto coconut charcoal. Environ Sci Pollut Res 20:2210-2219

$\mathrm{Xu} \mathrm{YH,} \mathrm{Nakajima} \mathrm{T,} \mathrm{Ohki} \mathrm{A} \mathrm{(2002)} \mathrm{Adsorption} \mathrm{and} \mathrm{removal} \mathrm{of}$ arsenic(V) from drinking water by aluminum-loaded Shirasuzeolite. J Hazard Mater B92:275-287

Xu W, Li LY, Grace JR (2012) Regeneration of natural bear river clinoptilolite sorbents used to remove $\mathrm{Zn}$ from acid mine drainage in a slurry bubble column. J Appl Clay Sci 55:83-87

Zelmanov G, Semiat R (2011) Iron Fe(III) oxide/hydroxide nanoparticles-based agglomerates suspension as adsorbent for chromium $\mathrm{Cr}(\mathrm{IV})$ removal from water and recovery. J Sep Purif Technol 80:330-337

Zhang L, Liu N, Yang L, Lin Q (2009) Sorption behavior of nano$\mathrm{TiO}_{2}$ for the removal of selenium ions from aqueous solution. J Hazard Mater 170:1197-1203

Zhou Y, Haynes RJ (2012) A Comparison of Water Treatment Sludge and Red Mud as Adsorbents of As and Se in Aqueous Solution and Their Capacity for Desorption and Regeneration. Water Air Soil Pollut 223:5563-5573

Zhou Y, Hynes RJ (2011) A comparison of inorganic solid wastes as adsorbents of heavy metal cations in aqueous solution and their capacity for desorption and regeneration. Water Air Soil Pollut 218:457-470

Zhu H, Jia Y, Wu X, Wang H (2009) Removal of arsenic from water by supported nano zero-valent iron on activated carbon. J Hazard Mater 172:1591-1596 